\title{
Az eurázsiai rétisáska (Stenobothrus eurasius) élőhelyi viszonyai a Kárpát-medencében - előzetes eredmények
}

\author{
Kenyeres Zoltán ${ }^{1}$, Bauer Norbert ${ }^{2}$, Cservenka Judit ${ }^{3}$ \& Szabó SzILÁrD $^{4}$
}

\author{
${ }^{1}$ Acrida Természetvédelmi Kutató Betéti Társaság, H-8300 Tapolca, Deák F. u. 7., Hungary, \\ e-mail: kenyeres@acridabt.hu \\ 2Magyar Természettudományi Múzeum, Növénytár, H-1089 Budapest, Könyves Kálmán krt. 40., Hungary, \\ e-mail: bauer.norbert@nhmus.hu \\ ${ }^{3}$ Balaton-felvidéki Nemzeti Park Igazgatóság, H-8229 Csopak, Kossuth u. 16., Hungary, \\ e-mail: cservju@gmail.com \\ ${ }^{4}$ Debreceni Egyetem, Természetföldrajzi és Geoinformatikai Tanszék H-4032 Debrecen, Egyetem tér 1., \\ Hungary, e-mail: szaboszilard.geo@gmail.com
}

\begin{abstract}
Kenyeres, Z., Bauer, N., Cservenka, J. \& Szabó, Sz.: Habitats of Eurasian Toothed Grasshopper in the Carpathian Basin - preliminary results.

Abstract: Eurasian Toothed Grasshopper (Stenobothrus eurasius) is a widespread Eurasian-Continental species, but in the Carpathian and Bohemian Basins, just isolated, relict stands of the species can be found. Our case study, being part of our detailed research on habitat requirements of Stenobothrus eurasius, carried out on two neighbouring hills of Eastern-Bakony (Bér-hegy and Móroc-tető) having very similar circumstances (in bedrock, exposure, geomorphology, vegetation). In order to compare potential and actual habitats of Eurasian Toothed Grasshopper, we collected data for almost a year (April to November 2017) regarding location, vegetation, microclimate and soil.
\end{abstract}

Keywords: Orthoptera, relict, steppe, habitat-preference, conservation

\section{Bevezetés}

Az eurázsiai rétisáska (Stenobothrus eurasius Zubowski, 1898) széles elterjedésű faj, mely areájának nyugati peremén, a Kárpát-medencében és a Cseh-medencében, izolált, reliktum jellegü állományokkal van jelen (SERGEev 1986, HolušA \& Holuša 2002, GaVlas 2005, NAGY \& Rácz 2014). Kárpát-medencei előfordulásainak zöme a Magyarközéphegység vonulatához köthető. Számos helyről publikálták a Tornai-karszt, a Budai-hegység, valamint a Pilis területéről, de előfordul a Gerecse, a Vértes, a Bükk, az Eperjes-Tokaji-hegység és a Keleti-Bakony alkalmas élőhelyein is. A Magyarközéphegység vonulatától független kárpát-medencei előfordulások közül a Mecsekből (Pécs) és a Gutin-hegységből (Nagybánya) származókat több évtizede nem erősítették meg. Alföldperemi hegyekről ismert a fajnak néhány, nem hazánkhoz tartozó, recens előfordulása Ausztriában (Hainburg: Braunsberg) és Szlovákiában [Nyitra: Zobor-hegy; 
Malé Kršteňan: Vel'ký vrch (irodalomban Oslany); Vinné: Vár-hegy]. A faj publikált elterjedési adatait és élőhely-választására vonatkozó eddigi ismeretek NAGY \& PUSKás (2007) összegezte. A rendelkezésre álló hazai információk alapján a St. eurasius különféle, többnyire déli kitettségü, sziklakibúvásokkal bíró, xeroterm élőhelyekről, sztyeprétről, erdőssztyepp foltokról, illetve sziklagyepekkel mozaikoló karsztbokorerdők térségéből került elő (NAGY 1974, Garai 1995, NAGY \& RácZ 1996, KisBENEDEK 1997, NAGY et al. 1998, NAGY et al. 1999, NAGY 2002).

A Stenobothrus eurasius közép-európai populációi sérülékenyek, az utóbbi évtizedekben több állomány esetében is visszaszorulás, illetve eltünés volt tapasztalható (NAGY \& PusKás 2007). A faj Kárpát-medencei populációinak hatékony megőrzését célzó programok tervezése csak a faj élőhely-választásának pontos ismeretében lehetséges. Ezzel a céllal 2017-2018-ban szisztematikusan felmértük az eurázsiai rétisáska állományait és élőhelyeit a Kárpát-medence 15, a faj regionális elterjedését jól reprezentáló mintaterületén. A faj élőhely-választásának megismerését célzó vizsgálataink részét képezte a Keleti-Bakony két nagyon hasonló adottságú (alapkőzet, fekvés, geomorfológia, növényzet), egymással szomszédos hegyén (Bér-hegy és Móroc-tetö) folytatott esettanulmányunk. A Bér-hegyen a St. eurasius egyik legerősebb hazai populációja él, ellenben a szomszédos, szinte minden élöhelyi adottságban igen hasonló Móroc-tetőn a szisztematikus keresések ellenére sem került elö a faj. Annak ismeretében, hogy a St. eurasius a Kárpát-medencében megtalálható potenciális élőhelyeinek csak a töredékén fordul elö, indokoltnak láttuk egy egyéves, a fenti két hegy élöhelyein párhuzamosan folytatott, vegetáció-, mikroklíma- és talajanalitikai vizsgálatokra kiterjedő kutatás elvégzését. Jelen közleményben a fenti esettanulmány eredményeit közöljük.

\section{Anyag és módszer}

A Tés községhatárában fekvő Móroc-tető és Bér-hegy a Keleti-Bakony két markáns dolomithegye. Az erdőterületek uralta hegyek délies kitettségű oldalain és platóperemein, valamint platóin a jó természetességi állapotú szárazgyep-területek kiterjedése jelentős. Az eurázsiai rétisáska potenciális élőhelyeinek felületborítása a Bér-hegyen - QGIS alapú becslésünk alapján - minimálisan 3 hektár, a Móroc-tetőn minimálisan 2 hektár. A Bér-hegy esetében a helyi állomány súlypontján, a Móroc-tetőn pedig az élőhely-szerkezet alapján a faj számára leginkább alkalmasnak tünő folton jelöltünk ki egy-egy $50 \mathrm{~m}$ × 50 m-es vizsgálati kvadrátot (kvadrátközéppontok: Bér-hegy 47¹2'54.15"É, $18^{\circ} 3^{\prime} 42.35^{\prime \prime K}$, Móroc-tető 47¹2'58.39"É, 18²'32.69"K).

A fenti kvadrátok területén a következő adatokat rögzítettük: St. eurasius lokális denzitása ( $1 \mathrm{~m} \times 50 \mathrm{~m}$-es transzekt vizsgálata alapján július második felében), alapkőzet, kitettség, lejtőszög, talajvastagság, 3 db növénycönológiai felvétel, növényzet vertikális borítása, nyílt talajfelszín aránya (\%), szabad kőzetfelszín aránya (\%).

A befoglaló egyenesszárnyú-együttesek vizsgálata céljából mindkét mintaterületen 4 alkalommal végeztünk fühálós mintavételezést (300 fühálócsapás a vizsgálati területen belül az alábbi napokon: 2017.05.27., 2017.06.30., 2017.07.18., 2017.08.15.).

A talajanalitikai vizsgálatok keretében mindkét kvadrátban két-két talajmintát vettünk, melyek alapján az alábbi változók átlagolt értékeit állapítottuk meg: a különböző frakciók [murva (2-4 mm), homok: nagyon durva (1-2 mm), homok: durva $(0,63-1 \mathrm{~mm})$, homok: középszerü $(0,63-0,2 \mathrm{~mm})$, homok: apró $(0,1-0,2 \mathrm{~mm})$, homok: finom $(0,1-0,05$ $\mathrm{mm})$, homok: por $(0,02-0,05 \mathrm{~mm})$, iszap: $0,01-0,02 \mathrm{~mm}$, iszap: $0,005-0,01 \mathrm{~mm}$, iszap: 
0,002-0,005 mm, agyag: 0,001-0,002 mm, agyag: <0,001 mm)] százalékos aránya, a

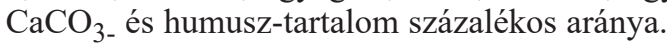

A mikroklíma-mérésekhez kvadrátonként kettő darab, TMS-2 típusú, földbe szúrt müszert telepítettünk. A müszerek 2017. április 1-től november 30-ig 3 ponton (talajfelszín alatt $10 \mathrm{~cm}$-re, talajfelszínen és talajfelszín felett $10 \mathrm{~cm}$-re) 10 percenként mérték és rögzítették a hőmérséklet értékeket. Mivel a müszerek jelentős részét a havonta történt ellenőrzések során gyakran kellett kitúrt/kiszedett állapotból újra visszahelyezni, csak a talajfelszíni mérések adatsorát használtuk. A kvadrátonként két mérömüszer adatsorainak átlagolásával állítottuk elő - havi bontásban - a vizsgálati területeken jellemző napi minimumok, napi maximumok, napi átlagok és napi hőingások box-plot diagramjait.

\section{Eredmények}

A Bér-hegyen a jelen vizsgálat 4 egyed $/ \mathrm{m}^{2}$ denzitású St. eurasius állományt tárt fel, míg a Móroc-tetőn a faj július-augusztusban több alkalommal, a teljes platót érintő, szisztematikus bejárások során sem került elö (ahogy a több mint 10 éve rendszeresen zajló bejárások során eddig egyszer sem). A vizsgálati területeken feltárt egyenesszárnyú-együttes szerkezete fajszám és diverzitás tekintetében nem mutatott számottevő eltérést $(\mathrm{SB}=10, \mathrm{SM}=12 ; \mathrm{HB}=0,186, \mathrm{HM}=0,148)$. Domináns fajok tekintetében fó különbség volt, hogy a Bér-hegyi együttes legnagyobb egyedszámban elökerült faja a St. eurasius volt, míg a Móroc-tető együttesében ugyanez a St. nigromaculatus-ról volt elmondható (utóbbi faj előfordult a Bér-hegyen is, de csak alárendelten). Az együttesek további domináns és szubdominás fajai nagyfokú egyezést mutattak és zömmel melegkedvelő, nyílt felszínekkel tagolt gyepekhez kötődő taxonok közül kerültek ki (a vertikálisan strukturált száraz gyepekben tipikus Platycleis grisea kivételével) - Bér-hegy: Oedipoda caerulescens, Calliptamus italicus, Chorthippus brunneus; Móroc-tetö: Calliptamus italicus, Platycleis grisea, Oedipoda caerulescens, Euchorthippus declivus, Chorthippus brunneus (1. táblázat).

1. táblázat: A vizsgált területeken feltárt egyenesszárnyú-együttesek, a fajok mintákban mutatott relatív gyakoriság értékeivel (domináns és szubdomináns fajok szürke kiemeléssel)

\begin{tabular}{lcc}
\hline Taxon & Bér-hegy & Móroc-tetó \\
\hline Stenobothrus eurasius Zubowski, 1898 & 0,283 & - \\
Oedipoda caerulescens (Linnaeus, 1758) & 0,253 & 0,125 \\
Calliptamus italicus (Linnaeus, 1758) & 0,131 & 0,175 \\
Chorthippus brunneus (Thunberg, 1815) & 0,111 & 0,100 \\
Platycleis grisea (Fabricius, 1781) & $\mathbf{0 , 0 8 1}$ & 0,163 \\
Euchorthippus declivus (Brisout de Barneville, 1848) & $\mathbf{0 , 0 6 1}$ & 0,113 \\
Stenobothrus nigromaculatus (Herrich-Schäffer, 1840) & $\mathbf{0 , 0 5 1}$ & 0,225 \\
Stenobothrus crassipes (Charpentier, 1825) & $\mathbf{0 , 0 1 0}$ & $\mathbf{0 , 0 2 5}$ \\
Decticus verrucivorus (Linnaeus, 1785) & - & 0,025 \\
Stenobothrus lineatus (Panzer, 1796) & - & $\mathbf{0 , 0 1 3}$ \\
Bicolorana bicolor (Philippi, 1830) & - & 0,013 \\
Leptophyes albovittata (Kollar, 1833) & - & 0,013 \\
Stenobothrus lineatus (Panzer, 1796) & $\mathbf{0 , 0 1 0}$ & - \\
Tettigonia viridissima (Linnaeus, 1758) & $\mathbf{0 , 0 1 0}$ & $\mathbf{0 , 0 1 3}$ \\
\hline
\end{tabular}


2. táblázat: Alapváltozók a vizsgált területeken

\begin{tabular}{lcc}
\hline Változó & Móroc-tetö & Bér-hegy \\
\hline St. eurasius denzitás (egyed $\left./ \mathrm{m}^{2}\right)$ & 0 & 4 \\
Alapközet & dolomit & dolomit \\
Kitettség & déli-délkeleti (S-SE) & déli-délnyugati (S-SW) \\
Lejtöszög & $5-10^{\circ}$ & $0-5^{\circ}$ \\
Talajvastagság & $3-5 \mathrm{~cm}$ & $3-4 \mathrm{~cm}$ \\
Növényzet vertikális borítása & rövidfüvü gyep & rövidfüvü gyep \\
Nyílt talajfelszín aránya & $5-10 \%$ & $5-10 \%$ \\
Szabad közetfelszín aránya & $5-10 \%$ & $10 \%$ \\
\hline
\end{tabular}

A két vizsgált élöhely az alapkőzet, a kitettség, a lejtőszög, a talajvastagság, a nyílt talajfelszín és a szabad kőzetfelszín aránya tekintetében lényegileg azonos körülményekkel volt jellemezhető (2. táblázat). A növényzet vertikális karakterisztikái alapján mindkét élőhely rövidfüvű gyepnek tekinthető, az élőhelyosztályozási rendszer kategóriái szerint a vizsgálati területeken előforduló gyepek többsége sziklafüves-lejtősztyeprét (Á-NÉR 2011: H2), kisebb részben sziklagyep (G2, G3). Az élőhelyek közös vonása a szerkezeti hasonlóság mellett a kontinentális flóraelemcsoport markáns jelenléte. A legjellemzőbb domináns gyepalkotó fajok a Festuca valesiaca agg. (incl. F. rupicola), a Carex humilis és a Melica ciliata, néhány állományban a Koeleria macrantha agg., a Phleum phleoides, a Stipa capillata és a Chrysopogon gryllus ér el magasabb borítást. A

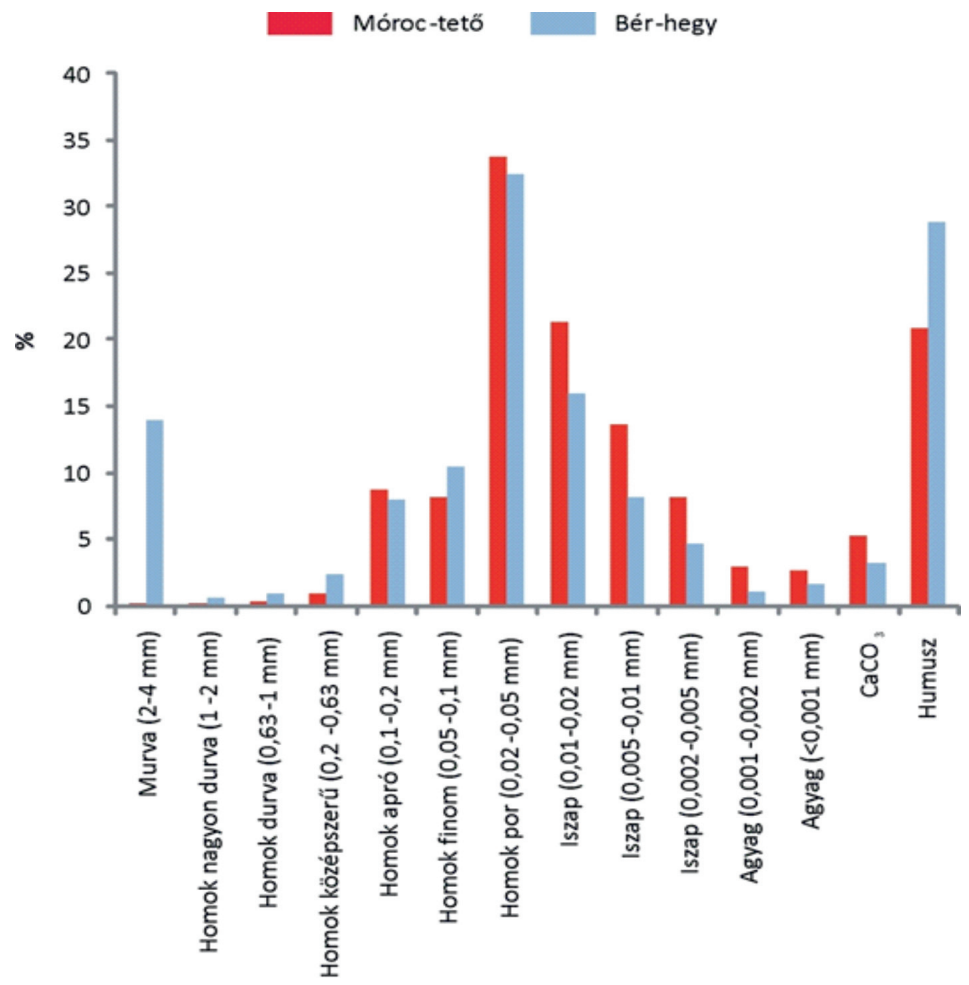

1. ábra: A vizsgált gyepterületek főbb talajtani jellemzői (az egyes frakciók százalékos aránya, valamint a talajok $\mathrm{CaCO}_{3}$ - és humusztartalma) 
St. eurasius élöhelyein a növényzet jó természetességi állapotú, a degradáció jellemzően kismértékü. A vizsgált faj élőhelyein a tipikusabb zavaró hatások, veszélyeztető tényezők a kirándulóturizmus eredetű taposás és a nagyvadak általi túrás - ezek azonban nem tekinthetők általánosnak, általában pont, ill. vonalszerüen jelentkeznek.

A talajminták elemzése élöhelyi különbségeket mutatott a két kvadrát között. Számottevőbb eltérés volt látható a talaj murva frakciójának és humusztartalmának százalékos értékeiben. Előbbi nem fordult elő a Móroc-tetői talajmintákban, a Bér-hegyen viszont csaknem $15 \%$-os részesedést mutatott. A humusztartalomnak a Móroc-tetői talajmintákban $20 \%$, a Bér-hegyen viszont $30 \%$ körüli részesedése volt mérhető (1. ábra).
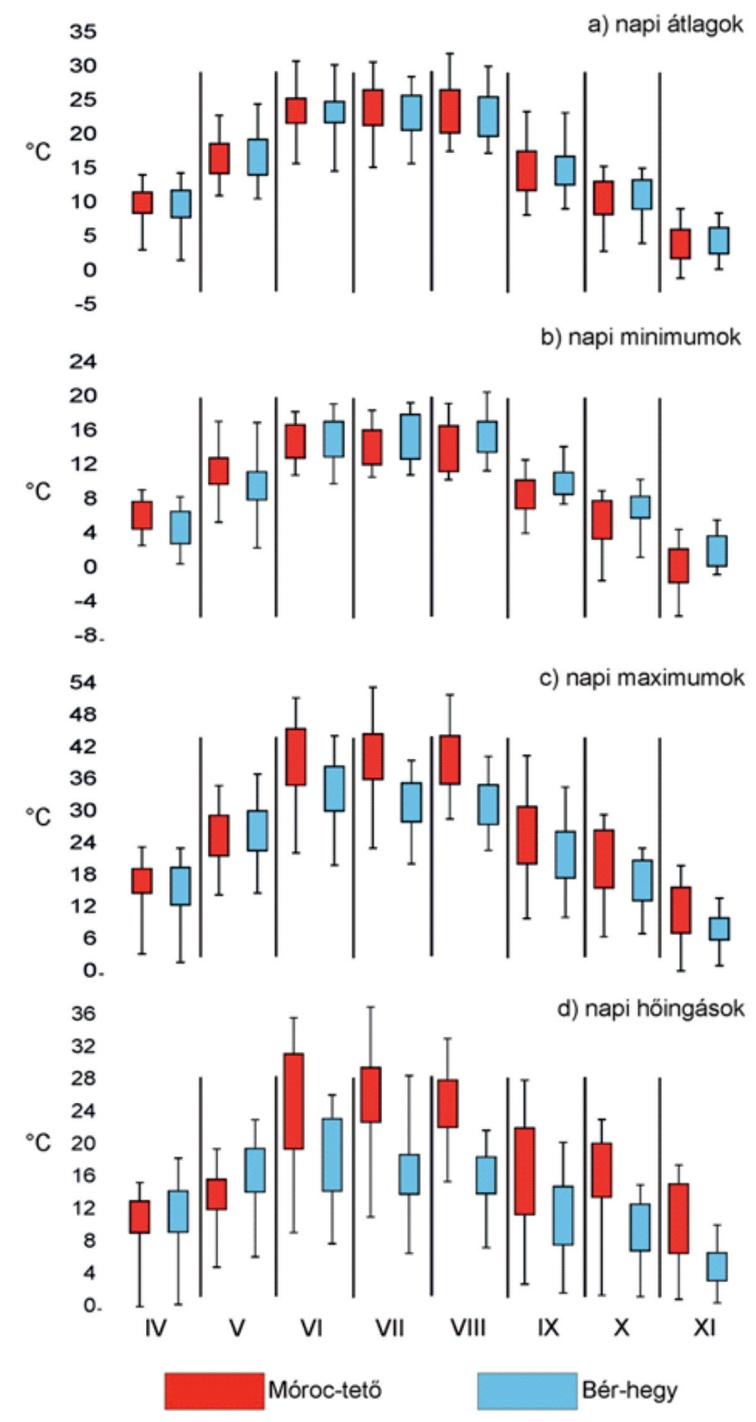

2. ábra: A vizsgált gyepterületek mikroklimatikus jellemzői a 2017. április-november időszakban 
A mikroklíma adatok (2. ábra) a napi átlaghőmérsékletek és a napi minimumok tekintetében nem mutattak különbséget a két élőhely között. A napi maximumok, és különösen a napi hőingások, június, július és augusztus hónapokban szignifikánsan alacsonyabbak voltak a Bér-hegyi mintaterületen, mint a Móroc-tetőn.

\section{Értékelés}

A St. eurasius élőhelyválasztására irányuló vizsgálataink első esettanulmánya természetesen nem adhat választ a faj megtelepedésének és fennmaradásának kérdéseire. Mivel korábban az élöhelyek talajtani és mikroklimatikus viszonyairól eddig nem rendelkeztünk adatokkal, néhány megfigyelésünk a faj élőhely-választásának megismerése felé tett első előzetes eredményeknek tekinthetők.

Mérési eredményeink szerint a faj nagy egyedszámú állományával jellemezhető élőhelyen magasabb humusztartalmú talaj van jelen. Ez alapot adhat egy zártabb, strukturáltabb gyepszerkezetnek, ami általában egy kiegyenlítettebb mikroklímát eredményez. Utóbbit, alacsonyabb napi maximumok és mérsékeltebb napi hőingás formájában a faj előfordulási területén jelen vizsgálat során detektáltuk is (különösen a június-augusztus időszakban). A temperáltabb mikroklíma akár meghatározó is lehet a faj megtelepedése/ fennmaradása szempontjából - mind az imágók kora nyári, nyári, mind pedig a tojások őszi, téli és tavaszi túlélése szempontjából.

Indokolt további vizsgálatok elvégzése annak eldöntéséhez, hogy a St. eurasius elöfordulásával, illetve hiányával jellemezhető gyepterületek élőhelyi körülményeiben az általunk feltárt különbségek valóban meghatározó fontosságúak-e a faj megtelepedése szempontjából. Feltétlenül meg kell jegyeznünk, hogy a jelen tanulmányban elemzettek mellé minden bizonnyal további tényezők (pl. tájtörténeti különbségek) vizsgálata is elengedhetetlen a faj élőhellyel kapcsolatos igényeinek és az aktuális elterjedési képének megértéséhez. 


\section{Irodalom}

GaRAI A. 1995: Adatok Magyarország Orthoptera faunájához. - Folia entomologica hungarica 56: 231-234.

GaVlaS, V. 2005: Orthoptera species of European importance in Slovakia. - Articulata 20(1): 57-68.

HolušA, J. \& HolušA, O. 2002: Occurence of the grasshopper Stenobothrus eurasius bohemicus (Caleifera: Acrididae) in the Czech Republic. - Articulata 17(1): 89-93.

KISBENEDEK T. 1997: Egyenesszárnyúak-Orthoptera. - In ForRó L. (szerk.): Nemzeti Biodiverzitás Monitorozó Rendszer V. MTM, Budapest, 55-81.

NAGy B. 1974: Reliktum Saltatoria fajok a pusztuló Bélkő hegyen. - Folia entomologica hungarica 27: 139144.

NAGY B. 2002: Védett és fokozottan védett egyenesszárnyú rovarfajok (Orthoptera) szerepe, jelentősége Magyarországon, fő tekintettel Nemzeti Parkjainkra és védett területeinkre. - MTI NKI Állattani Osztálya, Budapest, 23-24.

NaGy, B. \& Rácz, I. 1996: Orthopteroid insects in the Bükk Mountain. - In Mahunka, S. (ed.): The Fauna of the Bükk National Park, Hungarian Natural History Museum, Budapest, 95-123.

NAGy B. \& Puskás G. 2007: A Stenobothrus eurasius (Orthoptera: Acridoidea) előfordulása és élőhelyi jellegzetességei a Kárpát-medencében. - Folia Musei Historico-Naturalis Bakonyiensis 24: 35-57.

NAGY A. \& RÁCz I. 2014: Eurázsiai rétisáska Stenobothrus eurasius Zubovski, 1898. - In: HaraszThy L. (szerk.): Natura 2000 fajok és élőhelyek Magyarországon. Pro Vértes Közalapítvány, Csákvár: 202-204.

Nagy, B., RÁcz, I. A \& VARGA, Z. 1999: The Orthopteroid insect fauna of the Aggtelek Karst Region (NE Hungary) referring to zoogeography and nature conservation. - In MaHUnKA, S. (ed.) The Fauna of the Aggtelek National Park, Hungarian Natural History Museum, Budapest, 83-102.

NAGY, B., ŠuŠLIK, V. \& KRIŠTin, A. 1998: Distribution of Orthoptera species and structure of assemblages along Slanské-Zemplén Mountains Range (SE Slovakia - NE Hungary). - Folia entomologica hungarica 59: 17-27.

Sergeev, M. G. 1986: Patterns of Orthoptera distribution in North Asia. - Nauka, Novosibirsk 
